Vol 4, No 1 (2021): Stadium-Hungarian Journal of Sport Sciences https://doi.org/10.36439/shjs/2021/1/9458

\title{
A DÖNTÉS HÁTTERÉBEN ÁLLÓ KOGNITÍV KÉPESSÉGEK ÉS STRESSZ TOLERANCIA SZINTJÉNEK ÖSSZEHASONLÍTÓ ELEMZÉSE KEZDŐ ÉS TAPASZTALT SPORTOLÓKNÁL
}

\author{
COMPARATIVE ANALYSIS OF COGNITIVE ABILITIES STRESS TOLERANCE AND DECISION- \\ MAKING PROCESS IN NOVICE AND EXPERIENCED ATHLETES
}

Donka Dorottya Bianka, Balogh László,

Debreceni Egyetem Sporttudományi Koordinációs Intézet, Debrecen,

\section{Összefoglaló}

Bevezetés: Kiemelten fontos a csapatjátékokban, a kognitív képességek az érzékelés, észlelés, döntés (taktikai gondolkodás, tanulás, figyelem, gondolkodás, érzelmek) stressz tolerancia, sôt az ezek hátterében álló, a végrehajtás minőségét befolyásoló, motorikus képességek, technikai-taktikai képzettség szintje.

Célkitüzés: A játékintelligencia és stressz türőképesség vizsgálata során azt tapasztaltuk, hogy a kezdő/ fiatal és tapasztalt csapatsportolók stressz türőképességében van különbség (BALOGH, DONKA 2020). Az eredményeink azt mutatták, hogy a tapasztalt sportolóknak jobb a stressz tûrő képességük, azonban mivel ez egy leíró tanulmány volt, ezt az állításunkat szerettük volna nagyobb alanyszámmal is elvégezni, kognitív képességek vizsgálatának bevonásával is. Módszer: A kutatásunk módszere kísérlet. Keresztmetszeti vizsgálatot végeztünk 41 férfi és 13 nő csapatsportolón. Kognitív képességekre a VTS DT programcsomagját, stressz mérésre az MDE Heidelberg Stressz Holterét (gasztro, HR, TH, GSR) használtuk. A 35 perces mérés során az elsô szakaszban nyugalmi állapotot, a második szakaszban egy 10 perces stresszhelyzetre (kognitív tesztre VTS-DT) való reakciót, a harmadik szakaszban pedig egy megnyugvási állapotot, latenciát mértünk.

Eredmények: Szignifikáns eredményeket kaptunk, miszerint valóban van kapcsolat a nők és férfiak stressz türő és kognitív képessége között. A sportágak összehasonlítása során is szignifikáns eredményeket kaptunk, hiszen a futballisták minden más csapathoz képest rosszabban türték a stresszt, és többet hibáztak a VTS-DT teszt során. Következtetések: A jövőben a kezdő és tapasztalt kategóriába való besorolást egységesebben szükséges végezni, valamint a sportágak szerinti egyenlötlen alanyszámú részvétel sem kedvezó. Azonban bíztató, hogy a szignifikáns eredményeknél egyértelmü kapcsolat mutatható ki a stressz tûrőképesség és a jó döntések száma között. Ezek az eredmények további kutatási területeket tárnak fel számunkra. 
Vol 4, No 1 (2021): Stadium-Hungarian Journal of Sport Sciences

https://doi.org/10.36439/shjs/2021/1/9458

Kulcsszavak: döntési folyamat, kezdő és tapasztalt sportolók, stressz tolerancia és sport, stressz fiziológiai paraméterek, kognitív képességek,

\begin{abstract}
Introduction: Cognitive skills are essential in team sports. Perception, decision-making (tactical thinking, learning, attention, thinking, emotions), stress tolerance, and even the level of motor and technical-tactical skills all affect performance.

Objective: We found a significant difference in stress tolerance of novice / young and experienced team sport players (BALOGH, DONKA 2020). Our results showed that experienced athletes have higher level of stress tolerance. However, as this was a descriptive study, we intended to support our statement involving more number of subjects, and an analysis of cognitive abilities.

Method: A cross-sectional experimental study was performed on 41 male and 13 female team sport (handball, volleyball and football) players. We used the VTS DT software package for cognitive abilities and the MDE Heidelberg StressHolter (gastro, HR, TH, GSR) for stress measurement. During the 35-minute measurement process, a state of rest was measured in the first stage, a response to a 10-minute stress situation (VTS-DT for the cognitive test) in the second stage, and a state of rest and latency in the third stage.

Results: We found a significant relationship between stress tolerance and the cognitive ability of female and male participants. Our results demonstrated that football players had a lower level of stress tolerance than other team sport players. They also tent to make more mistakes in the VTS-DT test.

Conclusions: The classification into novice and experienced categories need to be done more uniformly in the future. We are aware of it, that the unequal number of participants by sports, is one of the limitations of our study. However, it is encouraging that significant results demonstrate a strong relationship between stress tolerance and the number of appropriate decisions. These results reveal other areas of research for us.
\end{abstract}

Keywords: decision-making process, novice and experienced athletes, stress tolerance and sports, physiological stress parameters, cognitive abilities 
Vol 4, No 1 (2021): Stadium-Hungarian Journal of Sport Sciences

https://doi.org/10.36439/shjs/2021/1/9458

\section{ELMÉLETI HÁTTÉR}

A sport fejlődésének következtében a teljesítményt befolyásoló tényezők szerepe kiemelt fontosságúvá vált. Az élsportban a sportteljesítmény eredményességének érdekében a sportolókat számos vizsgálatnak vetik alá, melyben nem csak a kondicionális és koordinációs képességeket elemzik, hanem egyre elterjedtebb a kognitív, emocionálisaffektív képességek módszeres vizsgálata is.

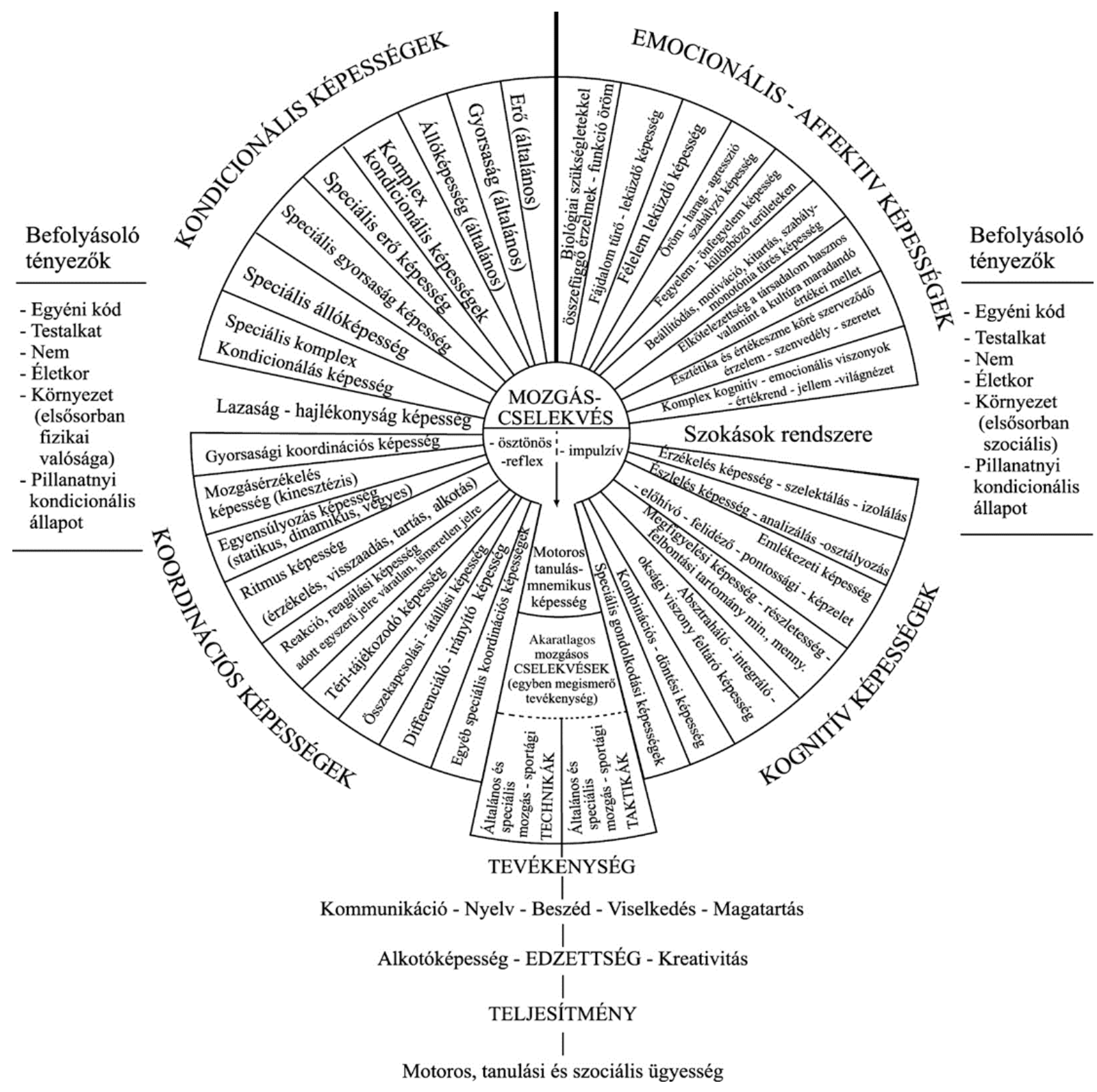

1. ábra: A sportteljesítményt meghatározó összetevők komplex rendszere, A „Dubecz-féle” hagyma

Forrás: (RADÁK, 2016) 
A csapat és labdás sportokban (látványsportokban) is megfigyelhető a technológiai fejlődés eredményeképpen a játékok kiemelkedően magas színvonalra való jutása. Kutatások hangsúlyozzák, hogy a technikai, taktikai felkészültség mellett nem elegendő a kondicionális és koordinációs képességek fejlesztése, hanem legalább ennyire fontos szerepe van az emocionális-affektív és kognitív képességeknek is (BALOGH et al., 2016; PUCSOK et al., 2018).

A játékintelligencia fogalma összefügg az eredményesség hátterében álló tényezőkkel. Azon sportolókat tartja a nemzetközi irodalom a legeredményesebbnek, legmagasabb játékintelligenciájú játékosoknak, akik döntéshelyzetben a legrövidebb idő alatt döntenek a lehető legjobban. Tehát, az érzékelés és az észlelés, valamint figyelemszelekciós folyamatai révén, képesek az adott döntési helyzetre a tanult és/vagy tapasztalt választ, a lehető leggyorsabban végrehajtani (BALOGH - DONKA 2020).

Vestberg kutatásában bizonyította, hogy a végrehajtó funkciók (EF) szerepe -ide tartoznak a kognitív képességek, melyek a gondolkodást és cselekvést is vizsgáljákmeghatározóak a játékintelligencia vizsgálatában, hiszen minél jobb egy sportoló végrehajtó funkciója, annál magasabb lesz a játékintelligenciája, tehát annál jobb játékos. (VESTBERG et al., 2017).

A játékintelligencia kiemelt tényezői a stresszhelyzetben való magas színvonalú teljesítés, mentális ellenállóképesség, valamint a döntéshozatal, anticipáció, stratégiai és taktikai végrehajtás. (ROCA et al., 2013).

A játékintelligencia gyakorlatban a döntéshelyzetben valósul meg. Az adott helyzetben ugyanis ki kell választani a megfelelő stratégiát melyben a döntés hátterében kognitív képességeknek a stratégia végrehajtásában pedig a koordinációs és kondicionális képességeknek van fontos szerepe. (LENNARTSON, 2015)

A játékintelligenciát Ward és Williams az öröklődés lehetősége és a korosztályok alapján vizsgálták és arra jutottak, hogy a tapasztaltabb játékosok sokkal hatékonyabban voltak képesek felidézni és felismerni az adott játékmintákat, mint kevésbé tapasztalt társaik (WARD - WILLIAMS, 2003).

Tehát kiemelten fontos a csapatjátékokban, a kognitív képességek az érzékelés, észlelés, döntés (taktikai gondolkodás, tanulás, figyelem, gondolkodás, érzelmek) stressztolerancia, sőt az ezek hátterében álló, a végrehajtás minőségét befolyásoló, motorikus képességek, technikai-taktikai képzettség szintje is. 


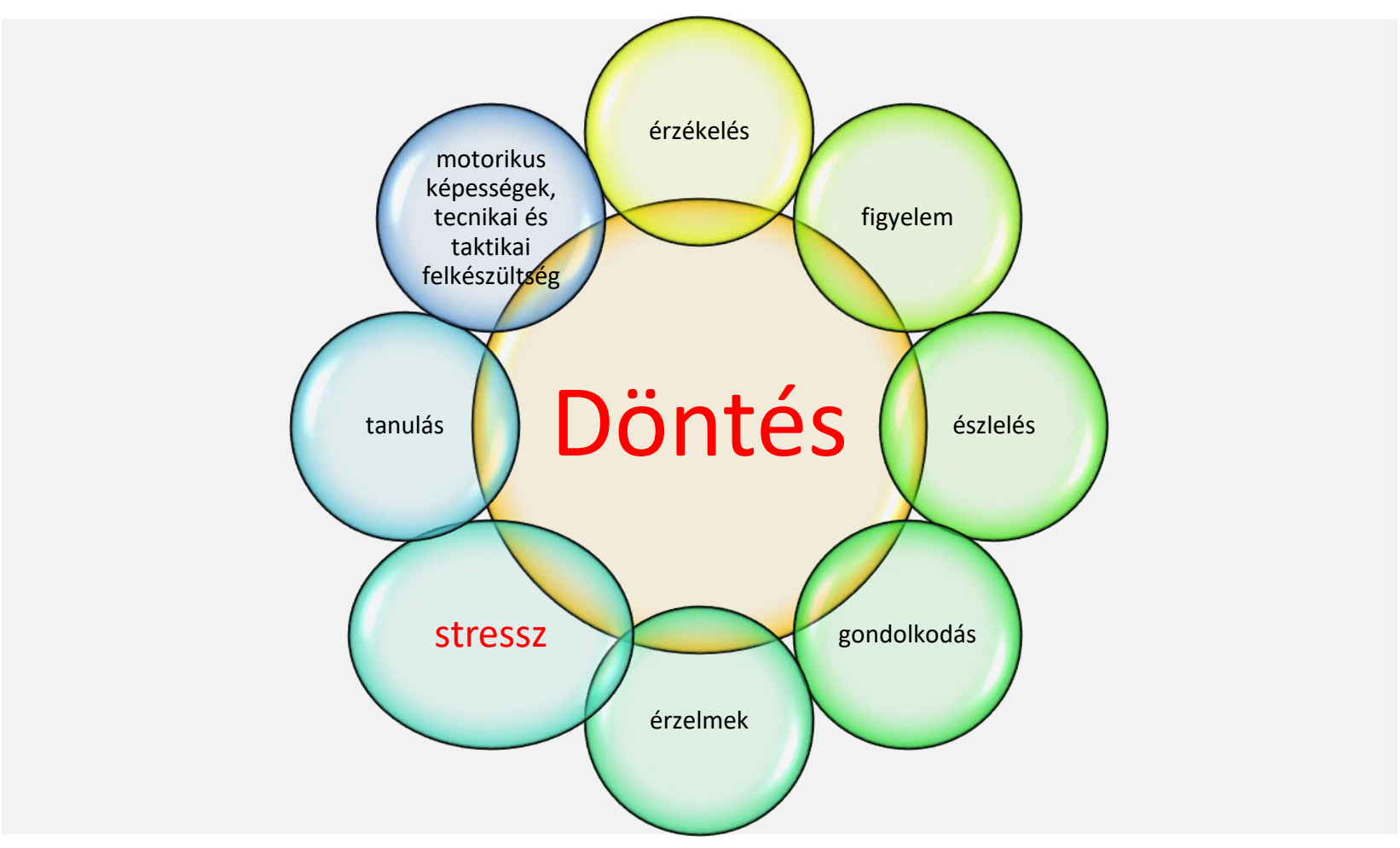

2. ábra A döntés hátterében álló komplex, pszicho-fiziológiai-motoros rendszer elemei (Balogh, Donka) alapján

\section{CÉLKITŰZÉS}

A játékintelligencia összetevői közül kutatásunkban kiemelten foglalkozunk a stressztúrő képességgel, és a döntés hátterében álló kognitív képességekkel.

A játékintelligencia és stressztűrő képesség vizsgálata során azt tapasztaltuk, hogy a kezdő/ fiatal és tapasztalt csapatsportolók stressztűrő-képességében van különbség (BALOGH- DONKA 2020). Az eredményeink azt mutatták, hogy a tapasztalt sportolóknak jobb a stressztűrő képességük, azonban mivel ez egy leíró tanulmány volt, ezt az állításunkat szerettük volna nagyobb alanyszámmal is elvégezni, más változók bevonásával is. Az eddigiekhez képest, így az sportolók négy különböző sportágból lettek bevonva (futball, futsal, kézilabda, röplabda), illetve már női sportolók is részt vettek a méréseinkben. Ezzel számos új kapcsolati lehetőséget fedezhetünk fel a különböző csapatok stressz tűrőképessége és kognitív képességei között. Érdekes irány lehet az egyes sportágakból származó sportolók eredményeinek összehasonlítása, valamint a csapatokon belül a tapasztalt és kezdő sportolók eredményeinek elemzése. Kérdés, hogy a tapasztalt és kezdő sportolók között találunk-e olyan összefüggést, ami a stressz tűrőképesség és döntés helyessége között mutat kapcsolatot.

A komplex kutatás kérdései és hipotézisei az alábbiak: 
K1: Van különbség a kezdő és tapasztalt csapatsportolók stressztűrő képességében és döntési eredményességében?

H1: Feltételezzük, hogy a tapasztalt csapatsportolóknak jobb a stressztűrő képessége, és ezért stresszhelyzetben jobb döntést hoznak, kevesebbet hibáznak.

K2: Van kapcsolat az sportolók stressztűrő és kognitív képességei között nemek tekintetében?

H2: Feltételezzük, hogy van kapcsolat a nők és férfiak stressztűrő és kognitív képessége között.

K3: Van összefüggés a különböző sportágból származó sportolók eredményeiben a stressztűrő és kognitív képességek viszonylatában?

H3: Feltételezzük, hogy összefüggés fedezhető fel az egyes sportágakban a stressztúrő és kognitív képességek viszonylatában.

\section{MÓDSZER}

A kutatásunk módszere kísérlet. Az adatokat a DE Sporttudományi Intézet Komplex Viselkedéselemző Laborjában vettük fel, két non-invazív eszközzel a VTS (Schufried, Bécs) és az MDE Heidelberg Stressz Holter (Heidelberg, Balatonfüred) rendszerével.

Magát a módszert illetően, a stressz mérésének műszeres eljárása széles körben elterjedt, de szinte kivétel nélkül csak a szívfrekvencia (HRv, és/vagy EKG) alapján. Az általunk alkalmazott módszer már nemzetközileg is validált, előzetes preklinikai és humán vizsgálatokkal igazolt (SZỨCS et al., 2018) komplex paramétereken nyugszik.

Az eredmények feldolgozását általános leíró statisztikával határoztuk meg (MS Excel 2020), illetve végeztünk T-próbát, valamint Mann-Whitney tesztet.

Minta:

- 10 futballista (DEAC NB3)

- 14 kézilabdázó (DEAC NB2)

- 7 férfi röplabdázó (DEAC NB1)

- 13 női röplabdázó (DEAC NB2)

- 10 futsal (DEAC NB1)

- átlagéletkor: $24,09+-3,88$

- átlag játékéletkor: $15+-4,93$

„Nem egyszerú kérdés tudományos alapossággal meghatározni, hogy ki a tapasztalt vagy kezdő. A naptári életkor mellett a sportágban eltöltött évek száma, de például a biológiai életkor is összetevő lehet. Mi a játékosokat, valamelyest kiküszöbölve az előző faktorokat, egyrészt a vizsgálati csoport átlagéletkorához képest neveztük tapasztaltnak vagy kezdőnek, mivel nincs erre standard meghatározás sem a nemzetközi sem a hazai irodalomban. Értelemszerűen, aki az átlagnál idősebb volt, az a tapasztalt, aki fiatalabb az 
a kezdő kategóriába került. Nemcsak az életkort átlagoltuk, hanem azt is megnéztük, hogy ki mióta foglalkozik az adott sportággal. Ez alapján is megkülönböztettünk tapasztalt, és kezdő sportolókat. Akik mindkét kategóriában tapasztaltnak bizonyultak, azok kerültek ebbe a kategóriába." (BALOGH- DONKA 2020) Továbbá, mivel sportág specifikusan több csoport is létrejött, (futsalosok, futballisták, kézilabdások, női és férfi röplabdások) ezért végeztünk külön sportági szintű kezdő-tapasztalt besorolást, valamint a teljes alanyszámra vonatkozólag. Erre azért volt szükség, mert az egyes sportágakhoz tartozó csapatokban más-más életkor volt a jellemző, és szerettük volna az egyes csoportokat külön-külön is megvizsgálni.

- DRF (DEAC RÖPI FFI) 25,57+-4,79 átlag életkor 13,42857143 +- 7,25 átlag játékéletkor

- DFU (DEAC FUTSAL) 22,1+-2,64 átlagéletkor 16,1+-3,14 átlag játékéletkor

- DRN (DEAC RÖPI NŐI) 22,85+-2,23 átlagéletkor 11,15+-3,51 átlag játékéletkor

- DF (DEAC FUTBALL) 24,5+-4,9 átlagéletkor 17,9+-3,57 átlag játékéletkor

- DK (DEAC KÉZILABDA) $25,71+-4,08$ 16,5+-4,7 átlag játékéletkor

A stressz hatást az MDE Heidelberg által kifejlesztett Elektrogasztrográfiás EGIG stressz holterrel mértük, mely egy non-invazív, realtime eredményeket adó műszer. „Az EGIG vizsgálati módszer a hasfalon elhelyezett 2 érzékelőjével, elektródájával alkalmas arra, hogy a gyomorban, valamint a vékony- és vastagbélben történő bio-elektromos változásokat monitorozza. Továbbá a két érzékelő valós időben, ugyanazon monitoron képes a szívfrekvencia variabilitás (HRv), a szív keringési rendszer (EKG), a testhőmérséklet (TH) valamint a bőr galvanikus ellenállásának (GSR) egyidejú mérésére. Ezzel egyedülálló módon az összes elfogadott olyan fiziológiai paramétert méri, amely a stressz hátterében áll, és nem csak egyik vagy másik alapján (pl. szívfrekvencia) jellemzi a stresszhelyzetet. Az adatok elemzésénél lehetőség nyílik a különböző bélszakaszok, mint pl. a vékony, illetve vastagbél mozgásának változásaival olyan összefüggések kimutatása is, amely az eddig vizsgálati eszközökkel nem volt lehetséges. Így lehetséges 
az is, hogy megfelelő elemszámú és több, különböző tevékenység és inger közben végzett méréssel kimutathatók lesznek az egyes stressz faktorok közötti különbségek" (BALOGH, 2016).

Korábbi kutatások alapján a gyomormotilitásból az elektromos aktivitás gyakoriságát CPM-ben, az aktivitás nagyságát pedig spektrumsűrűségként (PS) jellemezték (K.F. Szűcs et. al, 2018).

A mérésünk független változói az alábbi tényezők voltak:

- EGG (gyomor, vékonybél, vastagbél) FFT Teljesítmény max. PS, CPM

- DT-VTS kognitív teszt

A VTS-ST értékeli a reaktív stressz toleranciát és reakcióképességet a komplex ingerkörülmények között. A meghatározási teszt egy összetett, több ingerre adott reakcióteszt, amely magában foglalja mind a színes ingerek, mint az akusztikus jelek bemutatását, amelyre a válaszadó reagál a válaszpanel megfelelő gombjainak a megnyomásával és a pedálok használatával. A DT stresszként kezelhető, hiszen folyamatos, gyors és változó válaszokat kell fenntartani a gyorsan változó ingerekre. Mivel a teszt adaptív, a kitöltő szembesülhet olyan ingerekkel, melyek gyakorisága elég magas ahhoz, hogy kihívást jelentsen, vagy ne tudja a szükséges válaszokat végrehajtani, ezért felhasználható a pszichofizikai stressz különböző szintjein mutatott viselkedés vizsgálatára. A VTS-DT nemzetközileg is elismert és alkalmazott teszt a döntés hátterében álló kognitív képességek, reakcióidő vizsgálata során. (AMADO et. al., 2015)

A kiértékelés során a VTS-DT eredményeiből az összes válaszokat a jól megadott válaszokkal vizsgáltuk Fold Change módszerrel.

A protokoll menete a következő volt:

- 10 perc nyugalmi állapot

- kb. 12 perc stressz hatás (DT-VTS kognitív teszt végzése), a teszt végrehajtásától függött az időintervallum

- 10 perc latencia

(Az sportolóknak a mérés előtt 3 órával nem volt szabad étkezniük, a mérés előtt 4 órával nem ihattak energiaitalt, kávét, egyéb koffein tartalmú sportitalokat. A mérés az után kezdődött, hogy az alanyra felhelyeztük az elektródákat. Ezt követően indult el a nyugalmi szakasz, ahol az alany csendben ült egy széken, külső ingerek nélkül, laboratóriumi környezetben. Az első szakasz leteltével elindult az általunk itt megnevezett és más kutatások által (PATÓCS et al., 2016) is elfogadott stresszor egy kognitív teszt volt, a VTS DT. A sportolók ezt az egyszeri gyakorlástól és magától a kitöltéstől függően 15 perces tesztet önállóan végezték el. A kognitív teszt leteltével újabb 10 perc megnyugvási időt mértünk, így a mérés körülbelül 30-35 percig tartott egyénenként. A mérés közben biztosítottuk, hogy semmi külső inger ne zavarja meg az alanyt.) 
Vol 4, No 1 (2021): Stadium-Hungarian Journal of Sport Sciences

https://doi.org/10.36439/shjs/2021/1/9458

\section{EREDMÉNYEK}

Az eredmények kiértékelése során számos összehasonlítást végeztünk sportág, nem és játékéletkor alapján. Központi kérdésünk volt, hogy a tapasztalt, kezdő sportolók között jelentkezik-e a korábbi eredményeink alapján beigazolódott hipotézis, miszerint a tapasztalt sportolóknak jobb a stressztűrő képességük. A férfiakat és nőket ebben az értelemben is külön vizsgáltuk, és a teljes 'kezdő-tapasztalt' kiértékelésben a nők eredményei nem szerepeltek. Tehát a férfi futsal, futball, röplabda és kézilabda csapatsportolók eredményeit vettük alapul, és ez alapján az átlagéletkor, és átlag játékéletkor alapján különböztettük meg a kezdő és tapasztalt sportolókat. Így két csoportot: kezdő férfi sportolót, illetve tapasztalt férfi sportolót kaptunk. A változó értékek tekintetében (EGG (gyomor, vékonybél, vastagbél) FFT Teljesítmény max. PS, CPMDT; VTS kognitív teszt) T-próba következtében nem találtunk szignifikáns összefüggést. Természetesen ez nem jelenti azt, hogy a kezdeti hipotézisünket teljes mértékben el kell vetni, azonban a jövőben a kezdő és tapasztalt kategóriába való besorolást egységesebben szükséges végezni, valamint a sportágak szerinti egyenlőtlen alanyszámú részvétel sem kedvező. Az összesített értékeket tekintve tehát nem kaptunk egyértelmű eredményt, azonban az egyes csapatokat tekintve tendenciaszintű összefüggéseket találtunk.

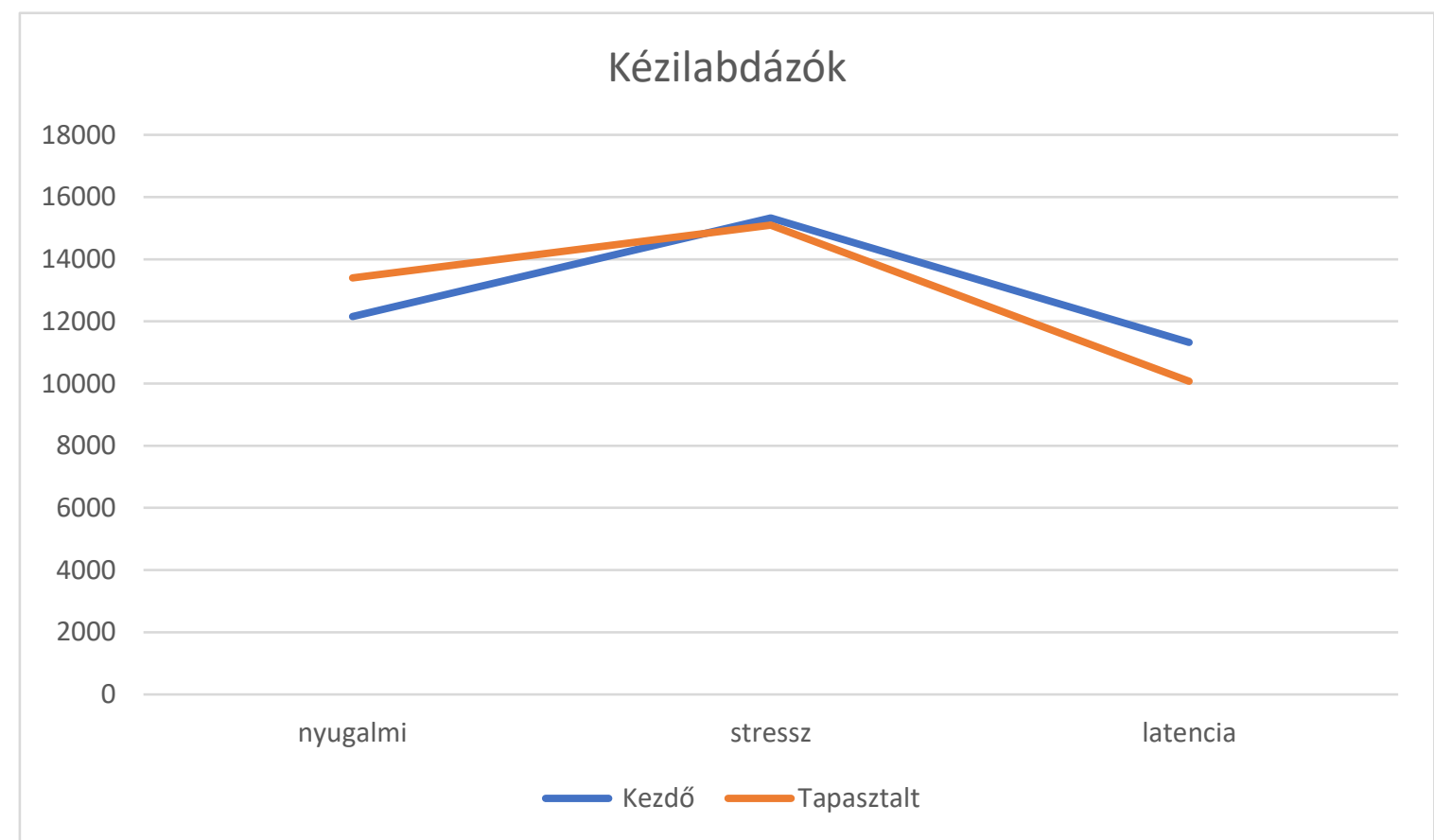

3.ábra A tapasztalt és fiatal kézilabdázók stresszre adott reakciója a gyomor-, vastag-, vékonybél Ps max átlagok alapján, nyugalmi, stressz és latencia szakaszban

Forrás: saját forrás

A 3. ábrán a kezdő és tapasztalt kézilabdázók EGG (gyomor, vékonybél, vastagbél) FFT Teljesítmény max. PS eredményei alapján jól látszik, hogy stressz hatására a gyomormotilitás nő, majd a stressz szakasz után, a megnyugvási szakaszban a kezdő nyugalmi állapot alá csökken. A tapasztalt kézilabdázók magasabb nyugalmi értékkel 
indulnak a kezdőkhöz képest, ez magyarázható azzal, hogy felkészülnek az adott stresszre, tehát van egy rákészülési szakasz. A stresszt követően viszont a nyugalmi helyzetben kapott érték alá csökken a PS érték, tehát hamarabb visszaáll a szervezetük az egyensúlyi állapotba, kezdő társaikhoz képest. A stressztürő képesség mellett vizsgáltuk a jó döntések számát az összes reakcióhoz képest, azonban itt nem találtunk érdembeli különbséget.

A nemek összehasonlításában T-próbát követően szignifikáns eredményeket $(\mathrm{p}<0,05)$ kaptunk. A gyomor Ps (FC) értékek alapján a szignifikancia $p=0,028$, a vékonybél Ps (FC) $p=0,017$, a vastagbél Ps $(F C)$ pedig $p=0,031$ volt. Tehát a nők szignifikánsabban jobb stressztúrő képességgel rendelkeztek, mint a férfiak. Érdekes továbbá, hogy a VTS-DT eredményeik alapján is csaknem szignifikánsan jobban teljesítettek p=0,088. Valószínűsíthető, hogy ha egyenlő számú férfi és női alany van, akkor ez az eredmény is szignifikáns különbséget mutatna. Ez az összefüggés bizonyítja, hogy azon sportolók, akiknek jobb a stressztürő képességük, jobban is teljesítenek a kognitív teszteken, tehát kevesebbet hibáznak.

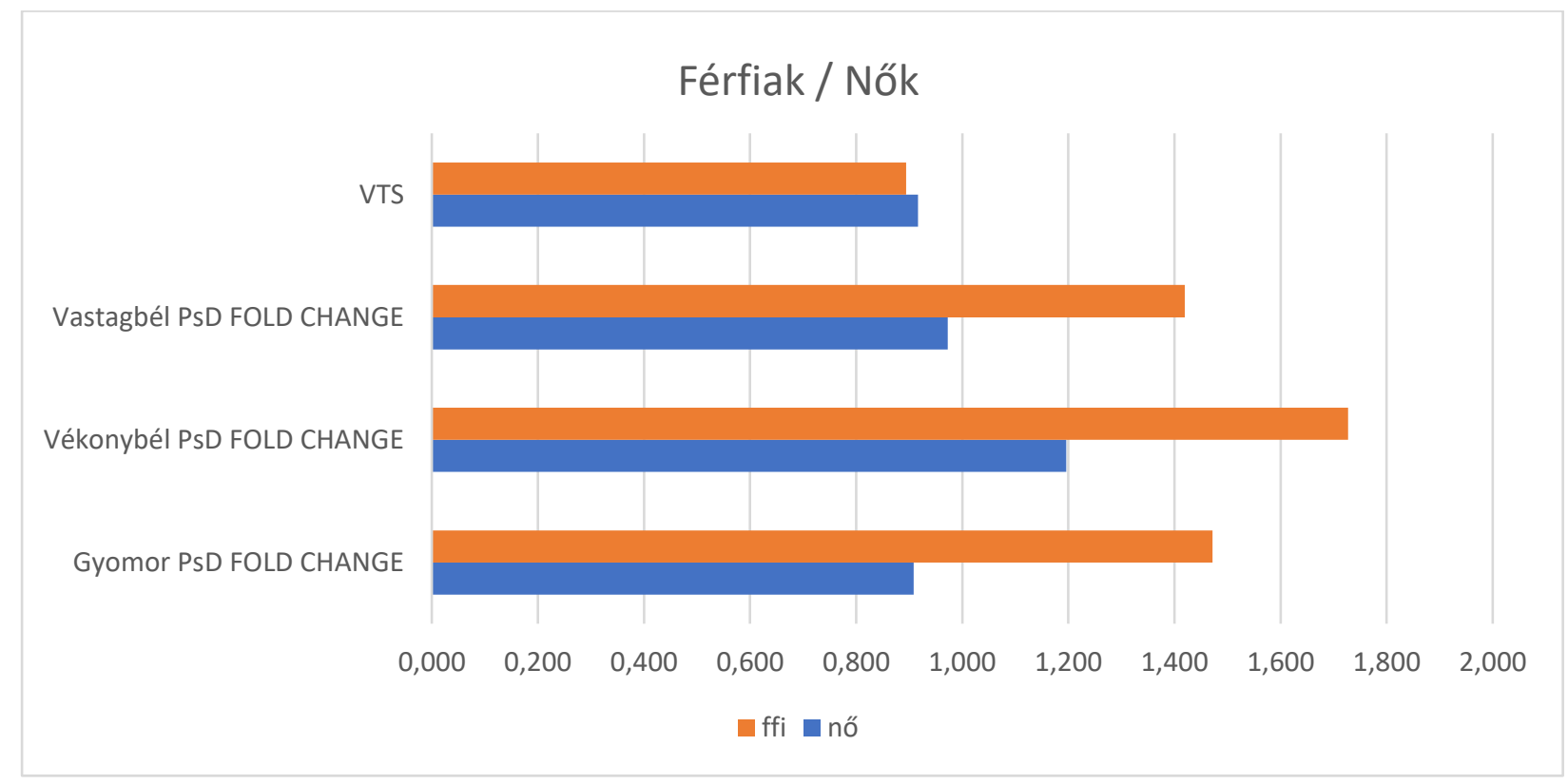

4. ábra A nök és férfiak stresszre adott reakciója az EGG (gyomor-, vastag-, vékonybél) FFT teljesítmény max. Ps átlagok alapján számolt Fold Change érték (nyugalmi-stressz szakasz)

Forrás: saját forrás

A sportágak összehasonlításában is találtunk kapcsolatot. A Mann-Whitney teszt segítségével szintén szignifikáns eredményeket kaptunk, ugyanis a DF, tehát futballista csapat szignifikánsan rosszabb eredményeket ért el mid a stressztürő képesség vizsgálatában, mind pedig a VTS-DT eredményeket tekintve, a többi csapathoz képest. A gyomor Ps (FC) értékek alapján a DRF-DF: $p=0,019$, DFU-DF: $p=0,005$, Dk-DF: $p=0,013$; a vékonybél Ps (FC) értékek alapján DFU-DF: $p=0,0003$; a vastagbél Ps (FC) értékek alapján DFU-DF: $p=0,012$, DK-DF: $p=0,042$ volt. A VTS eredményeit tekintve a DRF-DF kapcsolatában szignifikáns $\mathrm{p}=0,039$ eredményeket kaptunk. Tehát eredményeink alapján a futballisták szignifikánsan rosszabbul tưrték a stresszt, és többet is hibáztak a többi 
Vol 4, No 1 (2021): Stadium-Hungarian Journal of Sport Sciences

https://doi.org/10.36439/shjs/2021/1/9458

sportolóhoz képest. Ezen eredmények bizonyítják, hogy a túlzott stressz, tehát distressz hatására a döntés során többet hibáznak a sportolók.

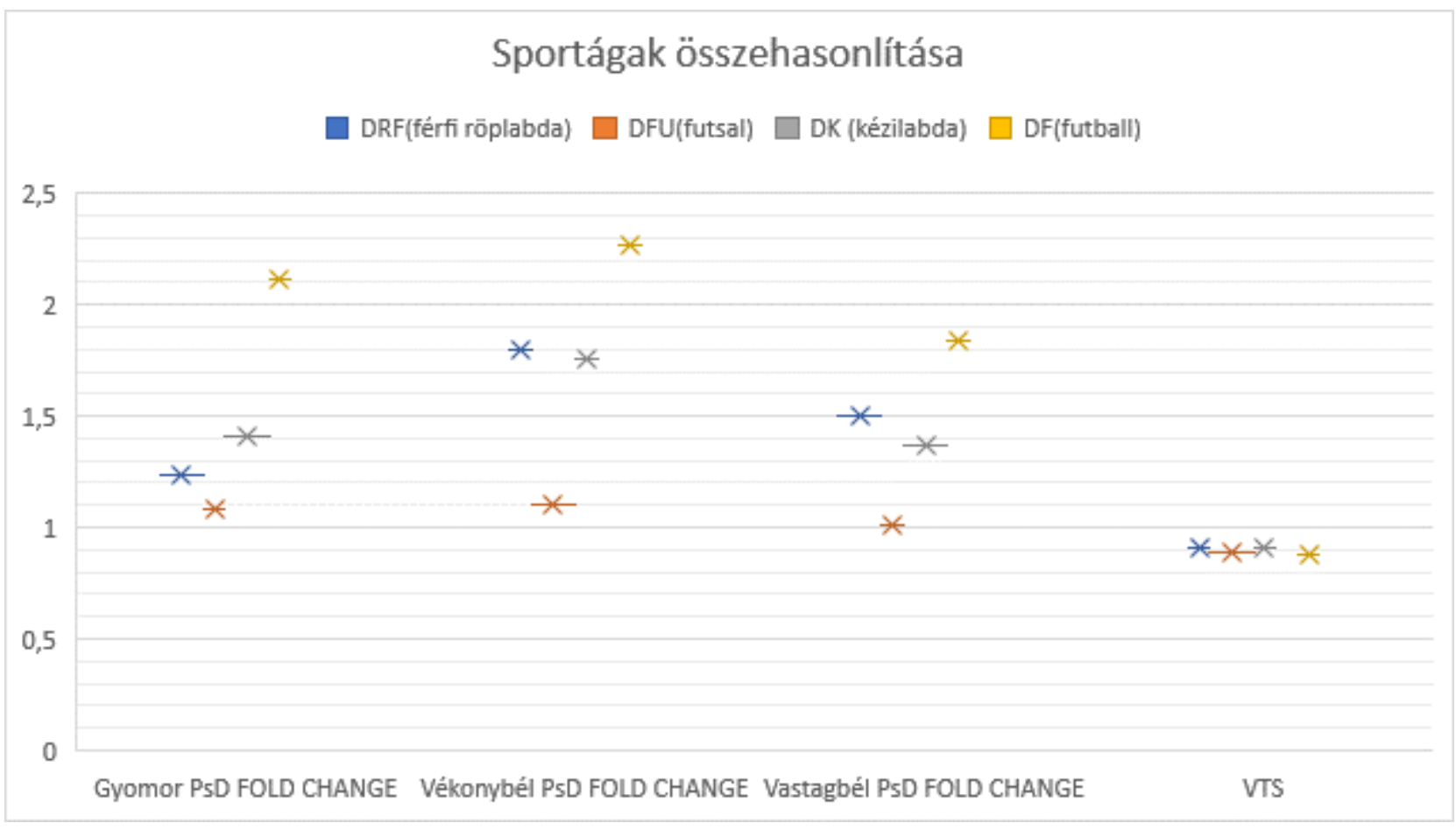

5. ábra Sportáganként a stresszre adott reakció az EGG (gyomor-, vastag-, vékonybél) FFT teljesítmény max. Ps átlagok alapján számolt Fold Change érték (nyugalmi-stressz szakasz)

Forrás: saját forrás

Az 5. ábra eredményei jól mutatják, hogy bár a futballisták valóban szignifikánsan rosszabb eredményeket mutattak, azonban velük szemben a futsal csapat nagyon jól tűrte az adott stresszt, és ennek megfelelően a jó döntéseik száma is magas volt. Érdekes lehet összehasonlítani a két csapatot, hiszen nagyon hasonló mozgásformával rendelkező sportágakról beszélünk. Az eredményeket befolyásolhatta, hogy míg a nagypályás futballban könnyebb egy-egy rossz döntést kijavítani, hiszen nagyobb a terület, addig a futsalban sokkal dinamikusabb játékra van szükség, nincs lehetőség annyit hibázni, és sokkal több döntést kell rövidebb idő alatt meghozni.

\section{MEGBESZÉLÉS}

A hipotéziseink alapján tehát:

K1: Van különbség a kezdő és tapasztalt csapatsportolók stressztűrő képességében és döntési eredményességében?

H1: Feltételezzük, hogy a tapasztalt csapatsportolóknak jobb a stressztűrő képessége, és ezért stresszhelyzetben jobb döntést hoznak, kevesebbet hibáznak.

Nem találtunk szignifikáns kapcsolatot, azonban az alanyszámok vizsgálatával, és a 'kezdő-tapasztalt' besorolás pontosításával érdemes további kutatásokat végezni, 
azonban tendenciaszerű összefüggéseket találtunk, ha sportáganként és nem összesítve vizsgáltuk a kapott eredményeket.

K2: Van kapcsolat az sportolók stressztűrő és kognitív képességei között nemek tekintetében?

H2: Feltételezzük, hogy van kapcsolat a nők és férfiak stressztűrő és kognitív képessége között.

Szignifikáns eredményeket kaptunk, miszerint valóban van kapcsolat a nők és férfiak stressztűrő és kognitív képessége között.

K3: Van összefüggés a különböző sportágból származó sportolók eredményeiben a stressztürő és kognitív képességek viszonylatában?

H3: Feltételezzük, hogy összefüggés fedezhető fel az egyes sportágakban a stressztűrő és kognitív képességek viszonylatában.

Szignifikáns eredményeket kaptunk, hiszen a futballisták minden más csapathoz képest rosszabban tűrték a stresszt, és többet hibáztak a VTS-DT teszt során.

Eredményeink alapján tehát szignifikáns összefüggést találtunk a nők és férfiak, valamint a sportágak szerinti összehasonlításában a stressztűrő képesség viszonylatában, valamint tendenciaszerü összefüggéseket kaptunk a kezdő és tapasztalt sportolók vizsgálata során. A kognitív DT-teszt eredményeiben a sportágak összehasonlításakor szignifikáns eredményeket, valamint a férfiak és nők eredményeiben tendenciaszerü összefüggéseket kaptunk.

A jövőben a kezdő és tapasztalt sportolók meghatározását pontosítani szükséges (ha a két csoport között nagyobb korkülönbség lenne, valószínűleg egyértelműbb eredményeket kapnánk), valamint több alany (pl. nők) bevonásával reprezentatívabb eredményeket kaphatunk. Az eddigi szignifikáns összefüggések azonban bíztatóak a jövőre nézve, érdemes a vizsgálatokat folytatni.

A kutatást az EFOP-3.6.1-16-2016-00022 Debrecen Venture Catapult Program támogatta. 


\section{IRODALOMJEGYZÉK}

Amado S., Koyuncu M., \& Kaça G. (2015). Comparison of three systems for psychotechnical assessment used in Turkey. Transportation research part F: traffic psychology and behaviour, 32, 78-90.

Balogh L., Petrovszki Z., Mikulán R., Nagy A., Dorka P., \& Molnár A. (2016). Akut pszichés stressz mérésére alkalmas, a gasztrointesztinális rendszer motilitásán alapuló diagnosztikai eszköz tesztelésének eredményei. In: Molnár, Andor; Balogh, László; Viorel, Ardelean Petru; Alattyányi, István; Győri, Ferenc (szerk.) SPORTTUDOMÁNYI KALEIDOSZKÓP: Sportszakmai tanulmány-, és szakcikk gyűjtemény Szeged, Magyarország: Szegedi Tudományegyetem Juhász Gyula Pedagógusképző Kar, 70-86.

Balogh L., \& Donka, D. (2020). A játékintelligencia és stressztűrő képesség vizsgálata tapasztalt és fiatal csapatsportolóknál VTS és innovatív, komplex MDE Heidelberg Stressz Holter eszközökkel. In: Trendek a versenysport és a szabadidősport területéről. Szerk.: Balogh László, Debreceni Egyetem Sporttudományi Koordinációs Intézet, Debrecen, 1220, (Válogatott tanulmányok a sporttudomány köréből, ISSN 2631-0910; 4) ISBN: 9789634902218

Lennartsson J., Lidström N., \& Lindberg, C. (2015). Game intelligence in team sports. PloS one, 10(5), e0125453. https://doi.org/10.1371/journal.pone.0125453

Nagy A., Almási D., \& Balogh L. (2016). Effects of acute psychological stress measurement in sports-EGIG, an innovative method to state stress response objectively. Arena: Journal of Physical Activities, (5).

Patócs Á., Melia L., Kovács S., Fózer-Selmeci B., Révész L., \& Tót, L. (2016). Reactive stress tolerance and personality characteristics of Hungarian elite fencers. Cognition, Brain, Behavior, 20(3), 171-184.

Pucsok J. M., Lenténé, Puskás A., Perényi, G., Varga, K., Bácsné Bába É., \& Balogh L. (2018). A Multi-Disciplinary Examination Of Psycho-Physiological Performance Among Youth And Junior Ball Sport Athletes - Systematic Review, Exercise Medicine 2 (2), 1-6.

Radák Zs. (2016). A sportteljesítményt meghatározó összetevők komplex rendszere, A „Dubecz-féle” hagyma. Edzésélettan. Krea-Fitt Kft, Budapest. 11-17.

Roca A., Ford P. R., \& Williams A. M. (2013). The processes underlying 'game intelligence'skills in soccer players. In Science and Football VII: The Proceedings of the Seventh World Congress on Science and Football (pp. 255-260). Routledge.

Szűcs G., Grosz M., Süle A., Sztojkov-Ivanov E., Ducza A., Márki A., Kothencz l., \& Balogh, R. G. (2018). Detection of stress and the effects of central nervous system depressants by gastrointestinal smooth muscle electromyography in wakeful rats, Life Sciences, 205, 1-8. 
Vol 4, No 1 (2021): Stadium-Hungarian Journal of Sport Sciences

https://doi.org/10.36439/shjs/2021/1/9458

Vestberg T., Reinebo G., Maurex L., Ingvar M., \& Petrovic P. (2017). Core executive functions are associated with success in young elite soccer players. PLOS one 12(2), e0170845. https://doi.org/10.1371/journal.pone.0170845

Ward P., \& Williams A. M. (2003). Perceptual and cognitive skill development in soccer: The multidimensional nature of expert performance.Journal of Sport and Exercise Psychology, 25(1), 93-111. 
Vol 4, No 1 (2021): Stadium-Hungarian Journal of Sport Sciences

https://doi.org/10.36439/shjs/2021/1/9458

\section{Függelék}

1. táblázat: Mérési eredmények, Forrás: saját forrás

\begin{tabular}{|c|c|c|c|c|c|c|c|c|c|}
\hline \multirow[t]{2}{*}{ kód } & \multicolumn{3}{|c|}{ Gyomor PS } & \multicolumn{3}{|l|}{ Vastag PS } & \multicolumn{3}{|c|}{ Vékony PS } \\
\hline & nyugalmi & stressz & latencia & nyugalmi & stressz & latencia & nyugalmi & \begin{tabular}{l|l}
$\mathrm{i}$ & stressz \\
\end{tabular} & latencia \\
\hline DK1 & 12584,3 & 17922,94 & 20877,67 & 11101,35 & 12170,76 & 20718,04 & 6230,434 & \begin{tabular}{l|l}
4 & 10290,65 \\
\end{tabular} & \begin{tabular}{l|l}
5 & 9445,755 \\
\end{tabular} \\
\hline DK2 & 3939,897 & 12977,41 & 6635,361 & 3251,698 & 14970,51 & 6463,531 & 2379,634 & \begin{tabular}{l|l|}
4 & 9597,321
\end{tabular} & \begin{tabular}{l|l|}
1 & 4614,451 \\
\end{tabular} \\
\hline DK3 & 18811,52 & 32685,92 & 20349,65 & 21209,51 & 38179,86 & 16625,95 & 7696,662 & 19561,63 & \begin{tabular}{l|l}
3 & 9422,286 \\
\end{tabular} \\
\hline DK4 & 24689,13 & 21202,25 & 15458,83 & 22614,58 & 19429,95 & 13561,69 & 8689,075 & \begin{tabular}{|l|l|}
5 & 11903,16 \\
\end{tabular} & \begin{tabular}{l|l|}
6 & 6986,462 \\
\end{tabular} \\
\hline DK5 & 33009,56 & 23928,1 & 12362,87 & 22423,81 & 17331,63 & 12955,5 & 18810,92 & \begin{tabular}{|l|l|}
2 & 12834,12 \\
\end{tabular} & \begin{tabular}{|l|l|}
2 & 12965,83 \\
\end{tabular} \\
\hline DK6 & 8173,103 & 9556,213 & 5674,533 & 14304,91 & 7769,004 & 4058,102 & 5855,323 & \begin{tabular}{l|l}
3 & 14259,67 \\
\end{tabular} & \begin{tabular}{l|l}
7 & 4921,642 \\
\end{tabular} \\
\hline DK7 & 22821,82 & 20691,13 & 12528,81 & 16708,35 & 14345,38 & 9659,906 & 14849,54 & \begin{tabular}{|l|l|}
4 & 17121,03 \\
\end{tabular} & \begin{tabular}{l|l|}
3 & 14846,42 \\
\end{tabular} \\
\hline DK8 & 24336,87 & 21990,62 & 13164,31 & 18463,89 & 16977,93 & 12975,14 & 18116,75 & \begin{tabular}{|l|l|}
5 & 10851,89 \\
\end{tabular} & 8757,847 \\
\hline DK9 & 10119,57 & 11712,83 & 11873,83 & 6429,956 & 8952,51 & 9972,874 & 3675,807 & \begin{tabular}{l|l|}
7 & 5245,614 \\
\end{tabular} & \begin{tabular}{l|l}
4 & 6100,748 \\
\end{tabular} \\
\hline DK10 & 16093,39 & 27281,42 & 10790,18 & 17082,46 & 24085,4 & 9907,784 & 9573,267 & \begin{tabular}{l|l}
7 & 15458,96 \\
\end{tabular} & \begin{tabular}{l|l}
6 & 4905,379 \\
\end{tabular} \\
\hline DK11 & 4379,883 & 6715,579 & 14739,73 & 3989,816 & 5122,069 & 11733,8 & 2734,713 & \begin{tabular}{|l|l|}
3 & 3817,136 \\
\end{tabular} & \begin{tabular}{l|l|}
6 & 6207,174 \\
\end{tabular} \\
\hline DK12 & 5902,868 & 15745,93 & 9712,601 & 5956,242 & 12345,99 & 13934,36 & 3320,23 & 12037,24 & 7598,797 \\
\hline DK13 & 13242,68 & 6912,444 & 6699,311 & 10922,93 & 5714,604 & 5832,074 & 9004,786 & \begin{tabular}{l|l}
6 & 6040,283 \\
\end{tabular} & \begin{tabular}{|l|l|}
3 & 3958,44 \\
\end{tabular} \\
\hline DK14 & 20990,89 & 24644,01 & 15275,21 & 18957,73 & 20693,76 & \begin{tabular}{|l|l}
5 \\
\end{tabular} & 13148,06 & \begin{tabular}{l|l}
6 & 17774,4
\end{tabular} & 13372,63 \\
\hline \multirow[t]{2}{*}{ kód } & \multicolumn{3}{|c|}{ Gyomor PS } & \multicolumn{3}{|c|}{ Vastag PS } & \multicolumn{3}{|c|}{ Vékony PS } \\
\hline & nyugalmi & stressz & latencia & nyugalmi & stressz & latencia & nyugalmi & stressz & latencia \\
\hline DF1 & 18292,14 & 42285,32 & 22413,86 & 25974,12 & 31084,86 & 19493,46 & 11478,51 & 23673,93 & 13952,67 \\
\hline DF2 & 23894,72 & 53275,27 & 26036,01 & 24844,68 & 29906,46 & 19090,81 & 11471,31 & 23276,98 & 13947,65 \\
\hline DF3 & 16476,71 & 23941,65 & 13785,87 & 12120,66 & 20053,15 & 15241,5 & 8696,826 & 25492,03 & 12475,12 \\
\hline DF4 & 20453,4 & 42795,74 & 30168,72 & 26475,88 & 38242,42 & 28381,8 & 12787,03 & 34182,63 & 17223,79 \\
\hline DF5 & 14647,98 & 26291,19 & 31795,43 & 10392,37 & 25343,91 & 21006,5 & 5343,851 & 12243,54 & 18085,52 \\
\hline DF6 & 6519,398 & 25991,71 & 28956,25 & 5151,168 & 21139,9 & 22840,23 & 9441,915 & 14534,26 & 22326,27 \\
\hline DF7 & 22688,1 & 28695,24 & 29182,76 & 17953,91 & 26136,95 & 25162,18 & 18629,58 & 24684,23 & 20936,84 \\
\hline DF8 & 9021,654 & 14980,07 & 10804,34 & 9950,176 & 12946,63 & 9384,783 & 6632,817 & 11478,3 & 6374,254 \\
\hline DF9 & 8739,032 & 23672,63 & 28956,14 & 6120,056 & 20159,45 & 23238,99 & 3922,913 & 15698,68 & 15893,52 \\
\hline DF10 & 13411,55 & 22324,9 & 9279,702 & 9784,222 & 23495,66 & 7945,001 & 6560,177 & 13472,76 & 5451,776 \\
\hline \multirow[t]{2}{*}{ Kód } & \multicolumn{3}{|c|}{ Gyomor PS } & \multicolumn{3}{|c|}{ Vastag PS } & \multicolumn{3}{|c|}{ Vékony PS } \\
\hline & nyugalmi & stressz & latencia & nyugalmi & stressz & latencia & nyugalmi & stressz & latencia \\
\hline DFU1 & 21687,4 & 53128,95 & 13726,83 & 16198,6 & 33123,79 & 10677,84 & 19475,3 & 30460,11 & 9279,461 \\
\hline DFU2 & 22934,34 & 37548,71 & 40864,31 & 24440 & 30044,38 & 29664,22 & 22312,94 & 29302,42 & 12602,86 \\
\hline DFU3 & 34559,32 & 21357,17 & 36612,12 & 36683,85 & 16632,25 & 32754,56 & 17095,33 & 8830,021 & 26516,27 \\
\hline DFU4 & 16947,93 & 8873,008 & 5984,049 & 13932,39 & 11495,37 & 4802,134 & 9242,537 & 7046,274 & 4338,442 \\
\hline DFU5 & 16448,96 & 16888,6 & 23158,99 & 13222,71 & 13802,58 & 19047,97 & 7865,931 & 11075,32 & 12891,56 \\
\hline DFU6 & 18650,64 & 19274,29 & 13651,94 & 19712,85 & 13939,21 & 9346,839 & 14672,09 & 19000,77 & 9665,054 \\
\hline DFU7 & 22599,31 & 8139,826 & 35053,21 & 17230,82 & 7431,161 & 30492,03 & 10084,84 & 4270,227 & 21806,81 \\
\hline DFU8 & 17608,42 & 15564,22 & 12673,17 & 11777,84 & 11260,99 & 9758,048 & 13226,98 & 18368,43 & 9447,064 \\
\hline DFU9 & 40677,01 & 20787,38 & 23747,61 & 37830,53 & 14578,22 & 18631,56 & 22723,66 & 17250,77 & 19205 \\
\hline DFU10 & 8894,404 & 15448,54 & 15278,13 & 5497,111 & 11185,44 & 10668,77 & 4956,019 & 8021,325 & 5646,518 \\
\hline
\end{tabular}


Vol 4, No 1 (2021): Stadium-Hungarian Journal of Sport Sciences https://doi.org/10.36439/shjs/2021/1/9458

\begin{tabular}{|c|c|c|c|c|c|c|c|c|c|}
\hline \multirow[t]{2}{*}{ Kód } & \multicolumn{3}{|c|}{ Gyomor PS } & \multicolumn{3}{|l|}{ Vastag PS } & \multicolumn{3}{|c|}{ Vékony PS } \\
\hline & nyugalmi & stressz & latencia & nyugalmi & stressz & latencia & nyugalmi & stressz & latencia \\
\hline DRF1 & 24167,69 & 37995,36 & 15641,89 & 23787,06 & 28875,43 & 11569,13 & 12194,07 & 50664,74 & 16185,69 \\
\hline DRF2 & & & & & & & & 22514,37 & \\
\hline DRF3 & 11517,27 & 38884,88 & 3821,25 & 9538,994 & 48280,85 & 75481,76 & 11567,15 & 47568,4 & 78440,88 \\
\hline DRF4 & 741,28 & 12831,93 & 15577,98 & 9185,404 & 11844,61 & 14510,11 & 9737,517 & 11620,24 & 6845,464 \\
\hline DRF5 & & 21659,66 & 21992,11 & 28667,62 & 41151,29 & 22471,52 & 14568,68 & 15355,24 & 1560 \\
\hline DRF6 & & 18742,58 & & & & & & & \\
\hline DRF7 & 22607,99 & 10028,12 & 4531,832 & 17294,69 & 6318,696 & 4202,499 & 15299,97 & 7857,091 & 5881,501 \\
\hline DRN1 & 10592,41 & 17352,11 & 6822,11 & 11264,74 & 21861,34 & 16404,25 & 7541,838 & 7615,381 & 437 \\
\hline DRN2 & & 17104,96 & & 11390,61 & 13098,5 & & 5092, & 9984 & 484 \\
\hline DRN3 & & 20552,73 & 14158,49 & 13453,17 & 20779,44 & 14130,12 & & 1111 & 941 \\
\hline DRN4 & 26845,7 & 26676,1 & 4662,309 & 23770,01 & 24737,51 & 5884,375 & 10909,54 & 13895,79 & 3675,973 \\
\hline DRN5 & 27977,65 & 17132,12 & 30515,86 & 30846,7 & 16493,44 & 45282,08 & 3,58 & 11819,54 & 5,86 \\
\hline DRN6 & & 15632,92 & & & & & & & \\
\hline DRN7 & 23392,03 & 20074,16 & 10141,51 & 20074,45 & 20918,59 & 10170,18 & & & \\
\hline DRN8 & 38127,99 & 24562,76 & 10751,31 & 37079,26 & 24965,67 & 8951,597 & 22216,24 & 15093,32 & 8255,46 \\
\hline DRN9 & 16059,26 & 13331,54 & 16373,88 & 9938,051 & 9995,396 & 10263,39 & 5679,874 & 4834,699 & 4002,016 \\
\hline DRN10 & 12415,94 & 10923,24 & 6596,046 & 11560,46 & 11115,09 & 5702,336 & 6664,117 & 8625,198 & \\
\hline DRN11 & 7588,574 & 3953,842 & \begin{tabular}{|l|}
7999,808 \\
\end{tabular} & 8223,652 & 2878,569 & 5395,004 & 4351,907 & 3027,804 & 6095,792 \\
\hline DRN12 & 21073,51 & 16933,52 & 8394,647 & 22411,51 & 19337,24 & 6686,887 & 10309,03 & 14636 & 5246,871 \\
\hline DRN13 & 34105,95 & 19092,32 & 12256,7 & 26411,35 & 15989,85 & 8420,776 & 14275,96 & 10110,2 & 5559,733 \\
\hline
\end{tabular}

